\title{
The Lautaro Basin: A record of inversion tectonics in northern Chile
}

\author{
Fernando Martínez', César Arriagada', Constantino Mpodozis², Matías Peña ${ }^{1}$
}

\author{
1 Departamento de Geología-Centro de Excelencia en Geotermia de Los Andes (CEGA-FONDAP), Universidad de Chile, Plaza Ercilla \\ 803, Correo 21, Santiago, Chile. \\ martinezfjh@hotmail.com; cearriarg@cec.uchile.cl; mapena@ing.uchile.cl \\ 2 Antofagasta Minerals, Apoquindo 4001, piso 18, Santiago, Chile. \\ cmpodozis@aminerals.cl
}

\begin{abstract}
The Triassic and Jurassic tectonic history of northern Chile has been dominated by extension, although clear evidence about the nature and geometry of the extensional basins and subsequent inversion structures has been adequately illustrated in only a few cases. In this contribution we present a structural study of the Lautaro Basin located at the western edge of the Frontal Cordillera in the Atacama region of northern Chile. The Lautaro Basin is a Jurassic half-graben, filled by at least 2,600 m of marine deposits of the Lautaro Formation and developed on top of, at least 2,000 $\mathrm{m}$ of Triassic volcanic successions of the La Ternera Formation, also accumulated during an earlier period of extensional deformation. Detailed field mapping and construction of a regional balanced cross-section, supported by good exposures along the Copiapó River valley, allow reconstruction of the structural style of both the Jurassic and Triassic extensional depocenters. New structural data have shown that the Lautaro Basin has a complex structural framework reflected in two major Mesozoic extensional periods, overprinted by Cenozoic inversion involving thin- and thick-skinned tectonics. Shortening was accommodated by a combination of inversion of pre-existing normal faults, buttresses, development of footwall short-cuts, and both thin and thick-skinned thrusting. New estimates of shortening are up to $13.1 \mathrm{~km}$ (30\%), while Mesozoic extension is estimated to be $3 \mathrm{~km}$ (7\%).
\end{abstract}

Keywords: Lautaro Basin, Half-graben, Balanced cross section, Inversion tectonics, Northern Chile.

RESUMEN. La Cuenca Lautaro: un registro de inversión tectónica en el norte de Chile. Durante el Triásico y Jurásico la evolución tectónica del norte de Chile fue dominada por extensión cortical. No obstante, evidencias claras acerca del estilo estructural y subsecuente inversión de las cuencas asociadas con el evento extensional, han sido ilustradas en pocos casos. En este trabajo, se presenta un estudio estructural de la Cuenca Lautaro, localizada en el borde occidental de la Cordillera Frontal, en la región de Atacama del norte de Chile. La Cuenca Lautaro, es un hemigraben que aloja al menos 2.600 m de depósitos marinos de la Formación Lautaro, acumulados sobre al menos 2.000 m de sucesiones volcánicas triásicas de la Formación La Ternera. Los excelentes afloramientos de la región permitieron construir una sección balanceada y restaurar el estilo estructural de los depocentros extensionales triásicos y jurásicos. Los resultados obtenidos muestran que la Cuenca Lautaro tiene una arquitectura estructural compleja, reflejada en dos episodios extensionales mayores. Posteriormente, se sobreimpone al menos un evento de inversión tectónica que desarrolla una tectónica mixta de piel fina y piel gruesa. El acortamiento se acomoda por una combinación de inversión de fallas preexistentes, desarrollo de fallas de atajo y corrimientos de piel fina y piel gruesa, que involucran bloques rígidos o ‘buttresses'. Las estimaciones de acortamiento son de 13,1 km (30\%), mientras que la extensión mesozoica es de 3 km (7\%). 


\section{Introduction}

Along the Andean Range, multiple lines of evidence show the great relevance of compressive tectonics related to the Mesozoic rift-basin closure. The present-day topography and crustal thickness of the central Andean plateu, composed of the Altiplano of Bolivia and the Puna in northwest Argentina and adjoining parts of Chile (Fig. 1a), is thought to be primarily a result of tectonic shortening and thickening (Isacks, 1988; Sheffels, 1990; Schmitz, 1994; Lamb and Hoke, 1997; McQuarrie and DeCelles, 2001), although an important characteristic within the architecture of these systems is the interaction between young compressive structures and extensional Mesozoic fault systems, which display complex patterns similar to those shown in the figure 2 .

This situation has been related to the tectonic inversion of extensional basins and has been recognized in the northern Andes in the Maracaibo Basin of Venezuela (Escalona and Mann, 2006; Martínez et al., 2010), the Eastern Cordillera of Colombia (Mora et al., 2006), and along the Central Andes in the Neuquén Basin (Cristallini et al., 2006; Dicarlo and Cristallini, 2007; Yagupsky et al., 2008), Cuyo Basin (Dellapé and Hegedus, 1995) and the Salta Rift (Cristallini et al., 1997; Carrera et al., 2006).

Tectonic inversion involves processes in which areas with negative relief are converted to areas with positive relief due to changes in the intracontinental stress regime (Cooper and Williams, 1989; Keller and McClay, 1995; Yamada and McClay, 2004). Although tectonic inversion processes are often assumed to occur by simple fault reactivation, several studies have shown that inverted structures may display complex geometries (Fig. 2), with pre-existing faults that can be either truncated by, or reactivated as, younger faults (Butler, 1989).

Recent studies in northern Chile, specifically in the Salar de Atacama Basin (Fig. 1a), which combining reflection seismic and outcrop data, show that it formed as a consequence of tectonic inversion of a Jurassic-Early Cretaceous back-arc basin within a continuous contractional regime in the Cordillera de Domeyko from mid-Cretaceous through Paleogene times (Muñoz et al., 2002; Mpodozis et al., 2005; Arriagada et al., 2006a; Jordan et al., 2007). It has been proposed that the main structural style of the Cordillera de Domeyko is strongly dependent on 'inherited structures', and that the shortening is due to reactivation of pre-existing extensional faults related to Triassic and Late Jurassic-Early Cretaceous rifts (Amilibia et al., 2008).

In northern Chile, on the western edge of the Frontal Cordillera (Fig. 1a), in contrast to other regions of the Central Andes such as the Sub-Andean Zone where abundant subsurface information from the oil industry is available, minimum estimates of horizontal shortening from restoration of balanced cross-sections have been hampered by a lack of available seismic information. Structural studies carried out in several morphostructural units along northern Chile, such as the thick-skinned, inverted Cordillera de Domeyko and the Coastal Cordillera, have traditionally emphasized motion along major N-S fault systems. In the other hand, the Paleogene deformation is more widely distributed across the Andes of northern Chile (Arriagada et al., 2000, 2003, 2006b; Taylor et al., 2007). Eocene-Oligocene deformation was accompanied by tectonic shortening, mountain uplift and significant clockwise block rotations (e.g., Hartley et al., 1992; Riley et al., 1993; Forsythe and Chisholm, 1994; Randall et al., 1996; Taylor et al., 1998; Arriagada et al., 2000; Somoza and Tomlinson, 2002; Arriagada et al., 2003, 2006b, 2008). Fission track thermochronology indicates that tectonic uplift and erosion were mainly active during the EoceneEarly Oligocene 'Incaic Orogeny', when at least 4-5 $\mathrm{km}$ of rocks were eroded during exhumation of tectonic blocks of the Cordillera de Domeyko between ca. 45 and $30 \mathrm{Ma}$ (Maksaev and Zentilli, 1999).

Although evidence of tectonic shortening and mountain building between the Late Cretaceous and the Tertiary seems reasonably well documented for the Andes of northern Chile (Moscoso and Mpodozis, 1988; Maksaev and Zentilli, 1999; Mpodozis et al., 2005; Arriagada et al., 2006a; Jordan et al., 2007; Amilibia et al., 2008), the complex interactions between extensional and compressional structures remain unresolved. Consequently, so far consistent evidence has not been shown to account for the structural style of the superposed Tertiary inversion. Only a few recent papers (Amilibia et al., 2008) have intended to describe the structures formed during the proposed extension-dominated period and those formed during inversion of the back-arc basins.

In this contribution we present the results of a detailed structural study of the Lautaro Basin carried out along the western edge of the Frontal Cordillera (Figs. 1a and b) and the geometry of a Jurassic 'back- 


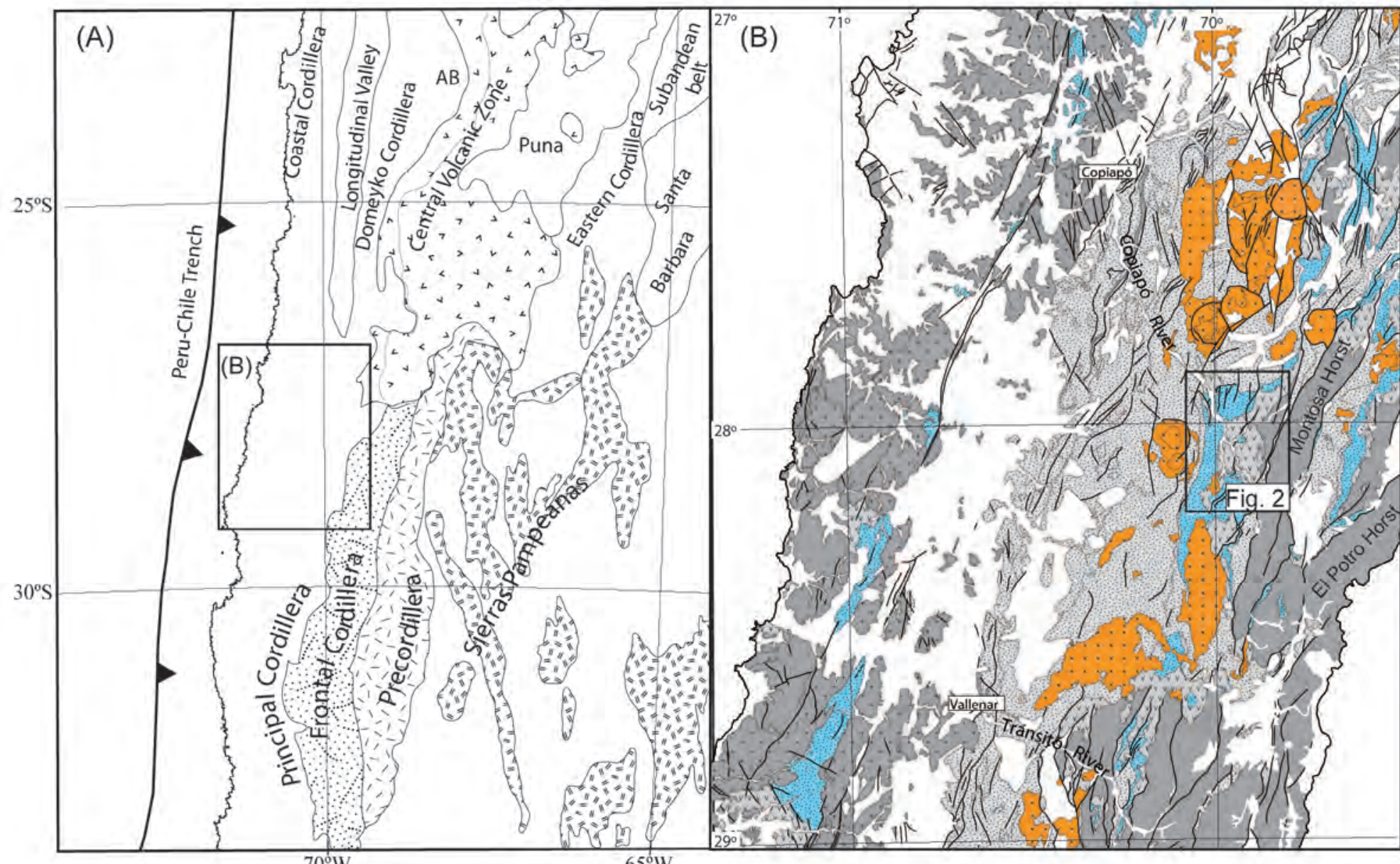
Paleozoic Basement
Jurassic stratified rocks

Jurassic-Cretaceous intrusives
Paleogene intrusives and volcanics

Cretaceous rocks

Neogene-Quaternary

FIG. 1. a. Main tectonic features of the Central Andes; b. Simplified geological map of the western margin of the Andes between $27^{\circ}$ and $29^{\circ} \mathrm{S}$ in northern Chile, showing the distribution and orientation of the major stratigraphic units. The box indicates the location of the study area. 
b)

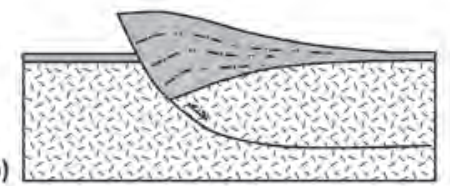

e)

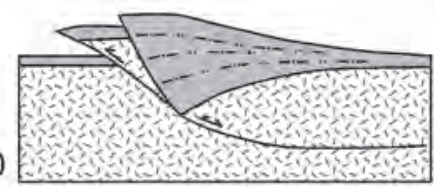

Syn-rift

[?] Pre-rift a)

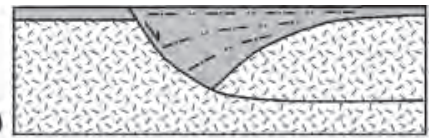

c)

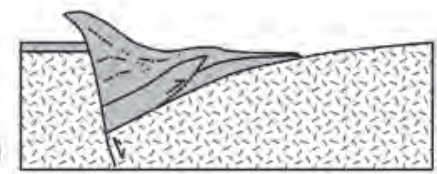

d)
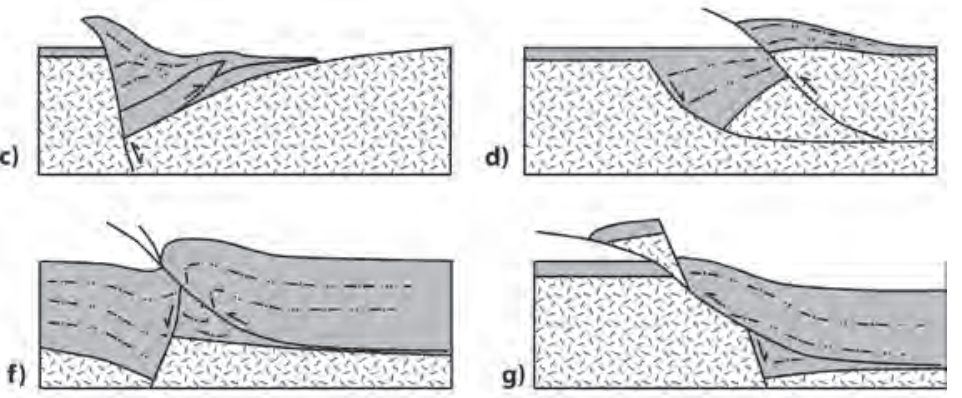

FIG. 2. Modes of possible inversion styles and thrust normal-fault interaction in orogenic belts: a. Early normal fault; b. Harpoon style developed from partially inverted normal fault; c. Buttressing; d. The hanging wall fault is faulted forming a 'hanging wall short-cut'; e. The footwall fault is faulted forming a 'footwall short-cut; $\mathbf{f}$. The early normal fault is folded and truncated by a younger thrust; g. The early normal fault provides stress concentration and promotes a thrust-ramp (modified from Butler, 1989).

arc basin', represented by an isolated half-graben depocenter in the Copiapó region. This area includes some of the type localities for the Jurassic in northern Chile and has been studied by numerous authors (e.g., Segerstrom and Parker, 1959; Segerstrom, 1968; Jensen, 1976, 1985; Von Hillebrandt et al., 1986; Soffia, 1989; Arévalo et al., 1994, Arévalo, 2005). A semi-arid climate and particularly the incision of deep canyons such as the Copiapó River valley, along which well-exposed structural relations can be observed, make it possible to outline the main episodes of deformation from pre-orogenic rifting to orogenic contraction.

After detailed mapping, field observations were included in a regional cross-section, which was balanced and restored using the 2D-MOVE (Midland Valley) software. The objective is to generate three geometrically compatible models that give us insights into the shortening estimates, geometry and kinematics of inversion tectonics. Additionally, we provide structural evidence to better constrain the style and timing of the early Mesozoic extensional tectonics in the Andes of northern Chile.

\section{Geological Setting}

The upper valley of the Copiapó River, at $27^{\circ}$ $28^{\circ} \mathrm{S}$ (Fig. 1b) is located along the northern section of the Chilean-Pampean Flat Subduction Zone (Cahill and Isacks, 1992). This segment is characterized by the absence of active volcanism and the presence of two major mountain belts, the Coastal Cordillera to the west and the Frontal Cordillera to the east (Fig. 1a). Within this scenario, the region forms part of the ranges located along the western edge of the Frontal Cordillera (Montosa Horst, El Potro Horst) that form the borderline with Argentina (Figs. 1a and b).

The Frontal Cordillera is shaped by a series of basement uplifts or 'basements horsts' (Godoy and Davidson, 1976) deformed in a thick-skinned style and bounded by high-angle east- and west-dipping reverse faults with a large vertical throw. The western edge is formed by thick Mesozoic successions accumulated in 'extensional' back-arc basins associated with the Late Triassic-Early Jurassic and Early Cretaceous extensional subduction (Mpodozis and Ramos, 1990, 2008). Lower Cenozoic volcanic and sedimentary strata are here intruded by coeval plutons. The latter were deformed in open, long-wavelength folds, including a thin-skinned, west-verging fold- and-thrust belt affecting Lower Cretaceous marine strata just to the west of the studied region (Segerstrom, 1968; Jensen, 1976; Moscoso and Mpodozis, 1988). The studied area contains stratigraphic and structural elements of both domains. 


\subsection{Regional stratigraphy}

\subsubsection{The Paleozoic Basement}

As stated before, the basement is formed essentially by Paleozoic granitoids similar to those that form the bulk of the Frontal Cordillera at this latitude (Montosa-El Potro Batholith; Fig. 1b; Mpodozis and Kay, 1990, 1992), being exposed along the eastern section of the studied transect as part of the $~ 100$ km wide fault-bounded 'Montosa Horst' (Godoy and Davidson, 1976; Figs. 1 and 3). Intrusives within this block are mainly to coarse-grained biotite-hornblende granodiorites and granites (Montosa Plutonic Complex, Jensen 1976; or Montosa Unit, Mpodozis and Kay, 1990, 1992). Farrar et al. (1970), Zentilli (1974) and Iriarte et al. (1999) have reported Permian to Triassic K/Ar ages that extend from 263 to $228 \mathrm{Ma}$, with the youngest probably representing not crystallization ages, but a Triassic (?) cooling event related to melting and crustal thinning (Mpodozis and Kay, 1990). Another, but smaller, outcrop of the plutonic basement occurs near the junction of the Jorquera and Pulido Rivers where the intrusives appear in the hanging wall of the east-verging El Chancho Thrust Fault (Fig. 3a). There, the intrusives (La Juntas Pluton; Jensen, 1976; Soffia, 1989; Iriarte et al., 1999) are coarse, pink biotite-hornblende monzogranites, quite similar to those that dominate the border area between Chile and Argentina (Cerro El Potro) to the east of the studied area (Permian, Chollay Unit of Mpodozis and Kay, 1992).

\subsubsection{Triassic-Early Jurassic, Synrift 1 succession: La Ternera Formation}

In almost all of the Atacama region the Paleozoic igneous basement is unconformably covered by Upper Triassic sedimentary successions that seem to have accumulated in a series of rift basins filled by Upper Triassic-Lower Jurassic strata. Those include marine clastic successions, various packages of fluvial or lacustrine deposits and/or thick volcanic successions (Segerstrom, 1968; Jensen, 1976; Suárez and Bell, 1992; Sepúlveda and Naranjo 1982; Reutter, 1974; Mpodozis and Cornejo, 1997). In the Tranque Lautaro region (Fig. 3a), La Ternera Formation (Solms-Laubach and Steinmann, 1889; Brüggen, 1950 ) is essentially volcanic and includes outcrops that at Rodeo uncomformably overlie granitoids of the Las Juntas Pluton. In the studied area the whole thickness of this unit is approximately 2,100 m
(Fig. 3b), being composed of continental clastic deposits which overlie the Paleozoic basement in onlap, together with andesitic and basaltic lavas in the upper part (Jensen, 1976). In the studied region it is mainly composed of andesitic to basaltic lavas. A Late Triassic-to Liassic age has been proposed by Soffia (1989) and Iriarte et al. (1999), because the uppermost volcanic levels of the formation on the west side of the Jorquera River (Fig. 3a) include a thin intercalation of marine limestones carrying Liassic fossils (Weyla sp., Rynchonella sp., Lythotrocus humboldti, Soffia, 1989).

\subsubsection{Jurassic, synrift growth succession 2: Lautaro Formation, Amolanas strata}

In the studied region the lavas of the La Ternera Formation are capped by a succession of Sinemurian to Bajocian marine carbonate-rich sedimentary strata (Lautaro Formation; Jensen and Vicente, 1976; Jensen, 1976, 1985; Soffia, 1989, Iriarte et al., 1999; Arévalo et al., 1994, Arévalo, 2005; Fig. 3). The Lautaro Formation and the correlative Amolanas strata (Fig. 3b) include red sandstones, grey limestones, calcareous siltstones and siltstone beds with Dactylioceras sp., Weylalata, Pholadomya cf. Plagemani, Oxynoticeras oxinotum, Arieticeras sp., Lytothrocus humboldti BUCH, Pholadomya litarenitas cf. Fidicula SOW, Deroceras cf. Davoei SOW, and Phymatoceras copiapensis, Rhynchonella variabilis, Rhynchonella andium, Terebratula punctata, Harpoceras falcifer, Peronoceras cf. Fibulatum and Dactylioceras sp., and other marine fauna (Segerstrom, 1968; Jensen, 1976) of Early Jurassic (Lias) age (Jensen, 1976; Jensen and Vicente, 1976). The total thickness exposed in the vicinity of Tranque Lautaro is approximately 2,600 m (Fig. 3).

One of the most striking features of the Lautaro Formation is its rapid thickness changes both acrossand along-strike. In the easternmost outcrops along the studied transect (Iglesia Colorada, Fig. 3) the formation includes $450 \mathrm{~m}$ of Toarcian to Aalenian sandy limestones, calcareous shales and reddish sandstones (Jensen, 1976; Soffia, 1989). The maximum thickness occurs to the west near the area of the Tranque Lautaro-Manflas River where the formation reaches $2.600 \mathrm{~m}$ of conglomerates, limestones, calcareous sandstones and shale of late Sinemurian to late Bajocian age (Jensen and Vicente, 1976; Jensen, 1976, 1985; Soffia, 1989; Iriarte et al., 1999). To the west of Quebrada Amolanas, the Lautaro Formation is 


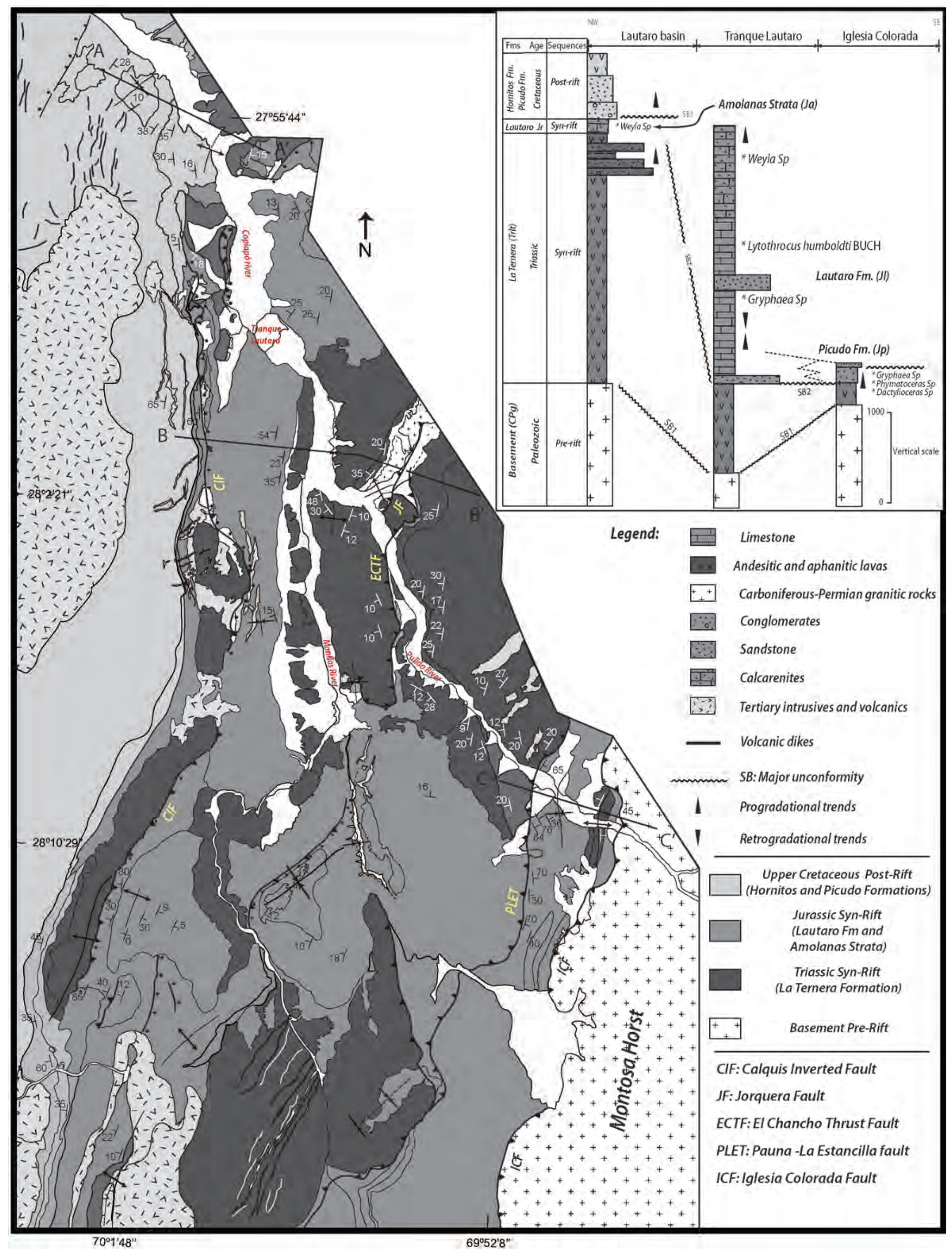

FIG. 3. a. Geological map of the Lautaro Basin. A-A', B-B', C-C’, indicate the locations of the section lines used for the construction of the balanced structural cross-section (Fig. 6); b. Generalized stratigraphic column, between Tranque Lautaro and the Iglesia Colorada area (modified after Jensen, 1976 and Soffia, 1989). 
replaced by a thinner sequence of no more than $200 \mathrm{~m}$ of well-bedded red calcareous sandstones, fine coarse conglomerates and red shales that lie directly on top of the La Ternera Formation volcanics (Amolanas Sequence, Jensen, 1976; Jensen and Vicente, 1976; Jensen, 1985; Soffia, 1989; Arévalo et al., 1994).

\subsubsection{Late Jurassic-Cretaceous post rift}

2.1.4.1. Picudo Formation. At the end of the Jurassic and during the Cretaceous large parts of the region were covered by continental red beds and volcanic strata (Picudo Formation, Reutter, 1974; Jensen and Vicente, 1976). In the Iglesia Colorada area these units are composed of up to $500 \mathrm{~m}$ of red sandstones and conglomerates (Fig. 3) capped by approximately $200 \mathrm{~m}$ of andesitic lava flows and pink ignimbritic horizons. These rocks are widely distributed in the southern Atacama region on the eastern bank of the Manflas River and further south of the Tránsito River (Reutter, 1974), where the Picudo Formation overlies the Lautaro Formation, the Triassic La Totora Formation or Paleozoic intrusives.

2.1.4.2. Hornitos Formation. Up to 2,200 m-thick continental deposits of the Hornitos Formation (Arévalo et al., 1994), accumulated between 85-60 Ma, are exposed to the west of Tranque Lautaro (Maksaev et al., 2009). The Hornitos Formation consists of breccias and conglomerates with a coarse sandstone matrix and lenticular intercalations of sandstone, calcareous mudstone and limestone (Fig. 3). Minor ignimbritic intercalations are also present. At its top, a continuous member of basaltic and trachybasaltic lavas is developed. The Hornitos Formation can be correlated with the Llanta Formation further north and is unconformably overlain by the Venado Formation (Sepúlveda and Naranjo, 1982) of Early Palaeocene age (Arévalo, 2005). These Upper Cretaceous strata are covered by a number of Paleocene-Eocene volcanic complexes, which include rhyolitic domes, some deeply eroded andesitic stratovolcanoes and numerous collapse caldera-deposits, which formed after a major compressive deformation event that took place around the Cretaceous-Tertiary transition (Arévalo, 2005).

\section{Structure}

The overall structural geometry of the studied region is depicted in the geological map of figure 3a. The Lautaro Basin is a broad NNE-SSE asymmetric depocenter infill by Mesozoic successions which include essentially units accumulated between the Late Triassic to Early Jurassic. Along the Copiapó River valley, between Tranque Lautaro and Iglesia Colorada (Fig. 3a), a set of N-S to NE-SW faults, arranged parallel or slightly oblique, forms the internal architecture of the Lautaro Basin. Inverted normal faults, reversed accommodation zones, reverse and thrust faults and related folding, are the structures most apparent in the basin. The deformation is not homogeneous and important variations occur in the tectonic style. Some faults have uplifted Paleozoic basement while other structures are essentially thinskinned faults. The structural context of the Lautaro Basin is defined as a mixture of structural styles including thick-skinned and thin-skinned tectonics.

The highest density of thin-skinned structures occurs along the western edge and the central region of the basin, where mainly syn-rift Triassic and Jurassic successions are involved in the deformation. Along the eastern edge of the basin the Paleozoic basement is uplifted along reverse faults (Fig. 3). According to the distribution and variations in structural style, the structure of the Lautaro Basin can be divided into three tectonic domains: Partially inverted, back-thrust and basement structures.

\subsection{Domain of partially inverted structures}

The main fault, termed the Calquis Fault, is a high angle $\left(80^{\circ}-85^{\circ} \mathrm{E}\right)$ structure which marks the western boundary of the Lautaro syn-rift deposits. It shows along-strike differences in orientation, from NNESSE in the south, to N-S in the north. In plan view the Calquis Fault is dissected by individual small faults, which appear to be relay ramp structures. The fault footwall, to the west, consists of volcanic rocks of the La Ternera Formation, whereas the hanging wall is constituted by marine deposits of the Lautaro Formation that dip westward against the Calquis Fault (Fig. 4a). In the hanging wall, the Lautaro Formation shows large variations in thickness in a wedge-like geometry (Fig. 3). Especially next to faults, progressive unconformities occur as evidence for synsedimentary extensional deformation during the accumulation of the Lautaro sediments (Fig. 4b).

The Lautaro synrift growth succession forms a typical inversion anticline, with a geometry defined as harpoon or arrowhead according to McClay (1995). This is characteristic of positive inversion where the 

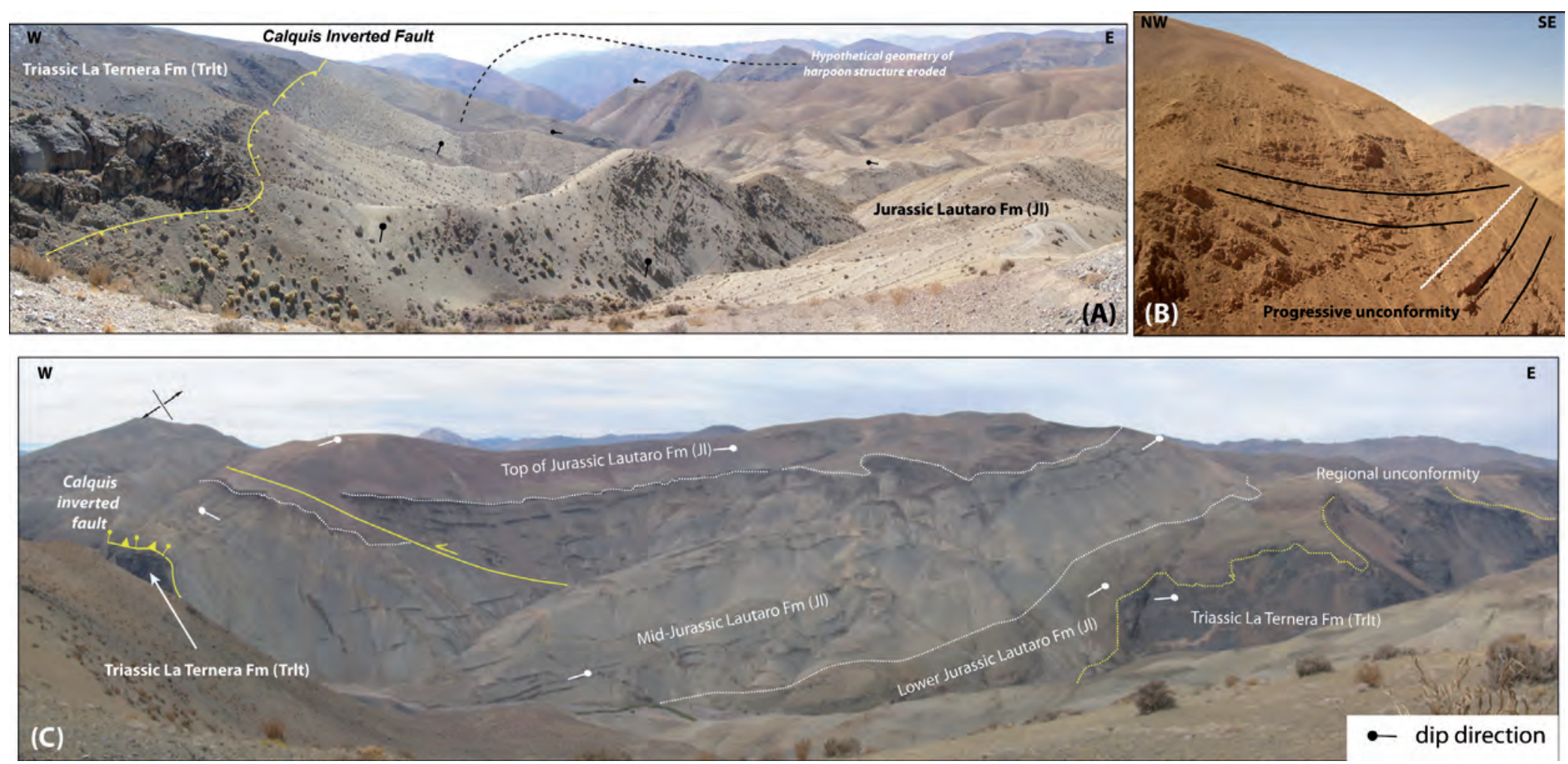

FIG. 4. a. Wedge geometry and harpoon structure, developed in the hanging wall of the Calquis Inverted Fault in the Manflas River region (see figure 3 for location). The syn-rift Jurassic succession of the Lautaro Formation consists of at least three units; b. Detail of progressive unconformities, observed near the Amolanas mine, in the hanging wall of the Calquis Fault, within Jurassic syn-rift series of the Lautaro Formation; c. Detail of the Jurassic syn-rift succession of the partially inverted Lautaro Formation, forming a spectacular harpoon structure, along an inverted normal fault, synthetic to the Calquis Fault, located in outcrops of the Manflas River. Notice the steep dips of the Lautaro rocks in contact with the Triassic beds of the La Ternera Formation. 
early extensional listric fault was reactivated as a contractional fault, suggesting that mild structural inversion occurred along the Calquis Fault (Figs. 4a and c). The Calquis Fault footwall is an anticline overturned to the west, which is interpreted here as a fault propagation fold above a westward-verging thrust, which we consider to be a short-cut rooted in the Calquis Fault (Figs. 3a and 6). Additionally, dyke-swarms are intruded following a similar trend to that of the Calquis and secondary faults.

Although this fault was first interpreted as a reverse fault by Arévalo (2005), the drastic facies change in the Jurassic wedge across the fault, the fact that the Lautaro Formation, dipping $80^{\circ} \mathrm{W}$ to subvertical in the hanging wall, abuts directly from the east against the fault trace, the eastward thinning out of the Lautaro Formation, and the occurrence of synsedimentary deformation just to the east, including small-scale progressive unconformities (Fig. 4b), indicate that the Calquis Fault developed as a normal fault that formed the western boundary of a half-graben in which the Lautaro Formation accumulated during the Jurassic. Further to the north, a thin slice of Jurassic limestones (Jensen, 1976; Jensen and Vicente, 1976) that overlies La Ternera strata in the Copiapó River valley near Tranque Lautaro, has been interpreted as a footwall syncline below a reverse fault (Jensen 1976; Jensen and Vicente, 1976; Arévalo et al., 2005). However, as shown below, buttresses played a significant role in the intense folding within the Lautaro Formation, especially in the vicinity of the Calquis Fault.

\subsection{Domain of back-thrust structures}

The central portion of the Lautaro Basin is traversed by several NNE-SSW striking faults which belong to an eastward-verging thrust system (Fig. 3a). The tectonic style of these contractional structures involves basement in the west and becoming thin-skinned in the east (Figs. 5b and c). Along the western border of the Jorquera River valley the $\mathrm{La}$ Ternera and Lautaro Formations are deformed in the footwall of an eastward-verging thrust (Jorquera Thrust, Fig. 3a) that brings the Paleozoic crystalline basement to surface (Fig. 5a). In the hanging wall of the Jorquera Thrust the syn-rift succesions of the La Ternera Formation form a NE-SW-trending anticline over the Paleozoic basement (Figs. 3a and 6). The Chancho Thrust lying immediately east of the Jorquera Thrust places the La Ternera Formation over the Lautaro Formation (Figs. 3a, $5 \mathrm{~b}$ and 6). Along the Pulido River valley, another NE-SW-trending, eastward-verging thrust defined as Pauna-La Estancilla Thrust places the La Ternera Formation over a thin section of the Lautaro and Picudo Formations (Figs. 3a, 5c and 6). Although in the study area the Pauna-La Estancilla Thrust appears to be thin-skinned, about $40 \mathrm{~km}$ to the north, along the fault trace, in the Jorquera River valley, an important zone of ductile deformation affects Paleozoic granites (Jensen, 1976; Soffia, 1989), suggesting a previous activity of the fault (Mesozoic?) located at deeper structural levels.

\subsection{Domain of basement structures}

Essentially a thick-skinned tectonic style characterizes the eastern boundary of the Lautaro Basin. The most important structural feature is the NNESSW-trending, westward-verging Iglesia Colorada Reverse Fault that displaced the Paleozoic crystalline basement over Jurassic-Cretaceous thin-skinned successions (Figs. 3a and 5c). The Iglesia Colorada Fault and the Pauna-La Estancilla Thrust are opposite-vergent thrusts and form a triangular zone whose inner part consists of highly deformed units containing thrust sheets belonging to the Lautaro and Picudo Formations (Figs. 5c, d and 6).

\section{Balanced cross-section}

The structure of the Lautaro Basin was interpreted by using balanced cross-sections along a transect across the study area (Fig. 3a). The transect trends NNW-SSE with a cross-strike distance of $\sim 30 \mathrm{~km}$. Because roads through the Copiapó River valley are not perpendicular to the trends of the main faults and fold axis, the integrated cross-section has three breaks allowing the cross-section to follow the mapped geology (Figs. 3a and 6). The breaks in the transect correspond to significant along-strike structures, allowing the cross-section to be accurately projected. The interpretations presented in the balanced cross-section are based on new mapping at a scale of 1:20,000 along the transect. The new mapping was compiled on 1:20,000-scale topographic maps in conjuction with existing geologic maps (1:100,000 and 1:250,000; Arévalo, 2005; Moscoso et al., 2010) to construct the cross-sections. 


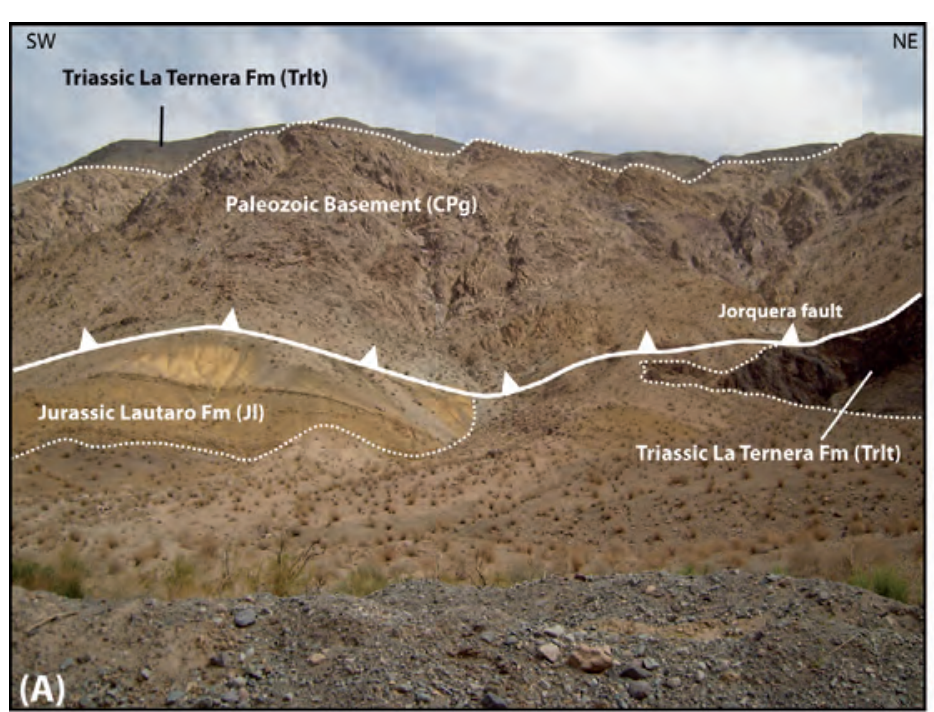

\section{(A)}

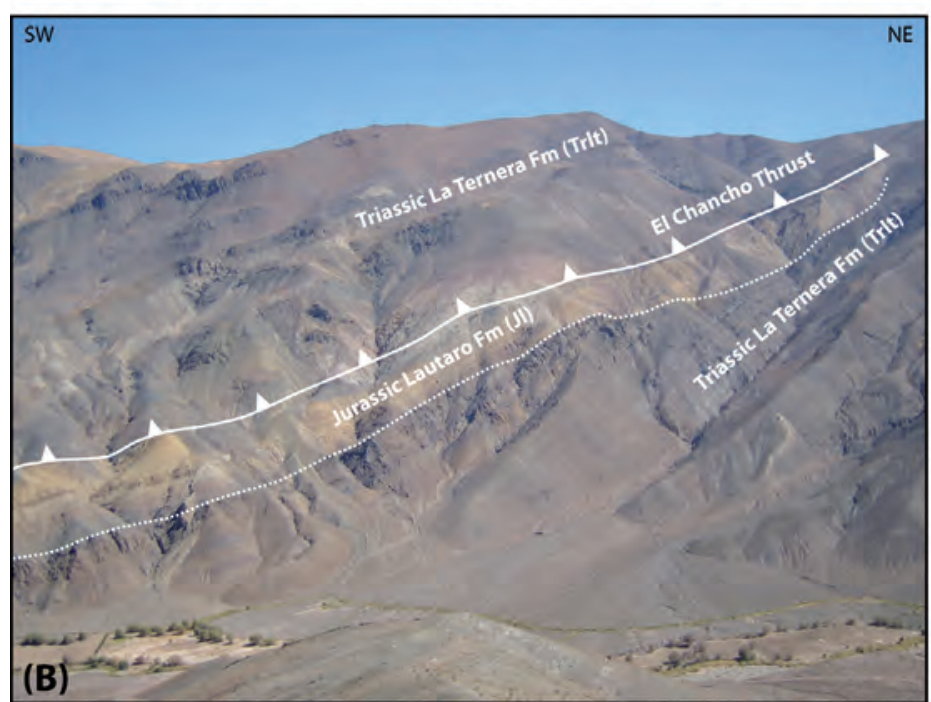

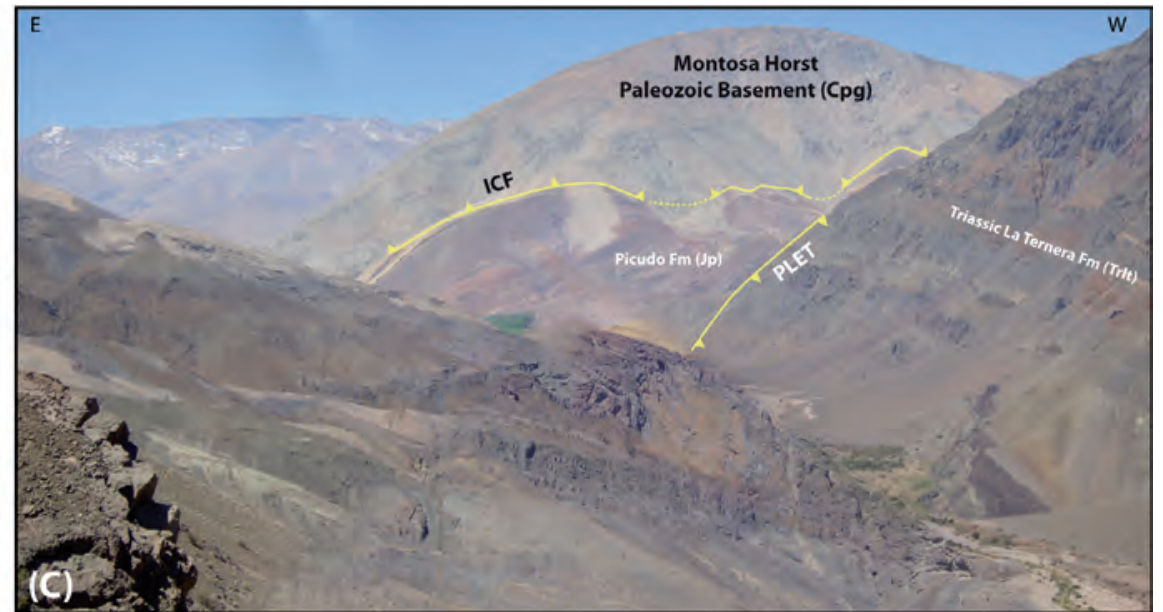

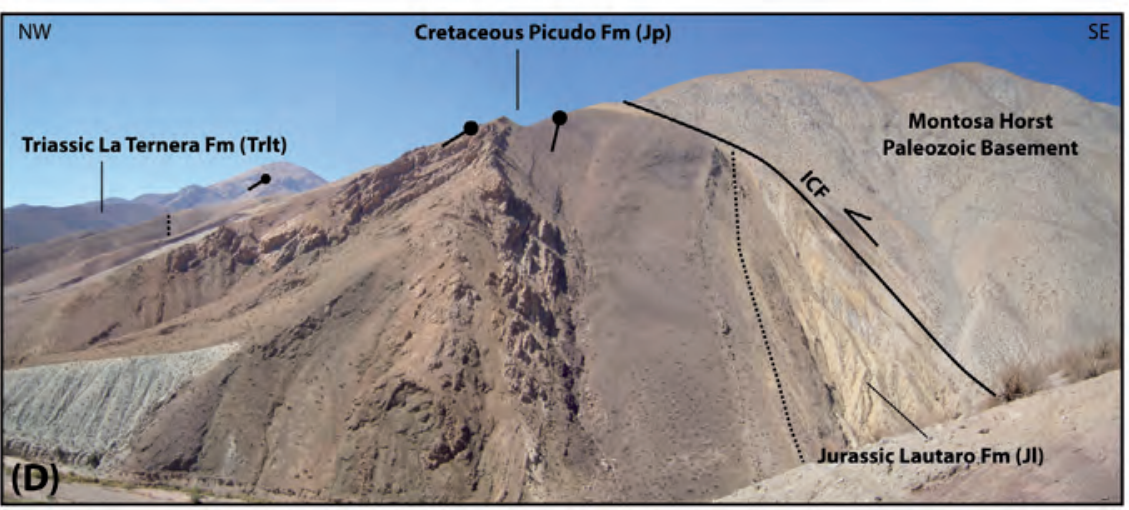

FIG. 5. a. Frontal view of the thick-skinned Jorquera Thrust; b. Partial view of El Chancho Thrust. Note how this thin-skinned structural feature repeats the Triassic successions of La Ternera Formation; c. Thick-skinned triangle zone observed in the Iglesia Colorada region. To the west the Pauna-La Estancilla Thrust (PLET), displaces Triassic rocks over the thin Jurassic Picudo Formation. To the E the Iglesia Colorada fault (ICF) displaces Paleozoic crystalline basement over the same Jurassic strata; d. Folding within Paleozoic basement core, which affects the Jurassic cover with a trishear deformation developed in the footwall of the Iglesia Colorada Fault. 
The balanced cross-sections were made using the kink axis method of Suppe (1983), Suppe and Medwedeff (1984), Suppe (1985), and Suppe et al. (1992). The sections were restored using combined methods such as the constant line and equal area using the flexural slip, inclined shear and trishear algorithms respectly. The balanced cross-sections and the accompanying undeformed sections were simulated using the computer program 2D-MOVE (Midland Valley) to produce sequentially restored sections that portray how the Lautaro Basin may have evolved through time.

\section{Structure of the Lautaro Basin}

We constructed three crustal scale models to explain the observed geometry and structural styles (Figs. 6a, b and c). In all three proposed models we interpret the regional structure of the Lautaro Basin as a partially inverted half-graben with related contractional structures. Structural and stratigraphic relationships that support this interpretation are as follows: The large variation in thickness of the Jurassic syn-rift Lautaro Formation in a wedge-like geometry and progressive unconformities provide strong evidence for coeval sedimentation and normal motions of the Calquis Fault during mid-Mesozoic times. The syn-rift growth succession was folded into a characteristic inversion anticline, and the eastwardverging back-thrusts and thick-skinned structures suggest that compressional deformation occurred during post-Jurassic-Early Cretaceous times. In all cases a rollover anticline formed in the hanging wall of the major Calquis Fault, which forms the western edge of the basin.

The models proposed to explain the structure of the Lautaro Basin are the following:

Model A. An inversion anticline formed in the hanging wall of the Calquis Fault and involved major thick skinned back-thrusting (Fig. 6a). In this model, a graben structure is considered to be located at the center of the basin with a major detachment to the eastward-verging, low-angle thrust system located in the Paleozoic basement. This situation could explain a greater displacement of the Pauna-La Estancilla Thrust, which NE of the basin has been clearly observed as a thick-skinned structure (Jensen, 1976) displacing the Paleozoic basement to the surface. In adition, the intense deformation and low thickness of the Mesozoic beds at the eastern side of the basin, suggest several possible mechanisms for the subsurface structure in this sector of the basin. In the other hand, this model always implies a large thickness for the La Ternera Formation in the footwall of the Iglesia Colorada Fault in the eastern side of the basin (Fig. 6a).

Model B. An inversion anticline formed in the hanging wall of the Calquis Fault and bivergent thrust systems (Fig. 6b).

Model C. An inversion anticline formed in the hanging wall of the Calquis Fault and mixed thin and thick-skinned back-thrusting (Fig. 6c).

The last two models assume a detachment from the eastward-verging low angle thrust located in the Triassic rocks (Figs. 6b and 6c) and have extensional structures that form an array of south-east dipping major synthetic faults (Figs. 6b and 6c). The models suppose that the thickness of the Mesozoic succession gradually decreases against the basement. In both cases (model B and C) the thick-skinned deformation in a first order fault such as the Iglesia Colorada Fault might well be distributed along imbricated thrust sheets (Mitra and Mount, 1998). Similar cases have been observed in the Bermejo Basin (Zapata and Allmendinger, 1996), in the Cordillera Frontal of Argentina (Giambiagi et al., 2003), in north-central Wyoming (Neely and Erslev, 2009) and the Andes of Mérida, Venezuela (Audemard, 1991).

Therefore, an inversion anticline on a basement wedge is the simplest way to explain the hanging wall geometry of the Calquis Fault. Inversion of this system caused that the buttressing of the synextensional strata folded in the hanging wall against the master Calquis Fault. Back-thrusting originated in previous normal faults and footwall short-cut thrusts can also be a consequence of buttressing against the master fault. Analogies to this structural style have been recognized and well documented in the Ecrins Massif, the western margin of the Alps (Mugnier and Huyghe, 1995; Butler et al., 2006), NE of the Bighorn Mountains in Wyoming (Stone, 2003), the pattern of inversed structures in the Cuyo Basin in Argentina (Uliana et al., 1995) and along the mountain front of the Frontal Cordillera in Argentina (Turienzo and Dimieri, 2005). Although all models have a set of thick-skinned inherent normal faults from the Late Triassic-Early Jurassic extensional stage (Figs. 6a and $6 \mathrm{~b}$ ), the Calquis Fault is the most important structure in this framework. 

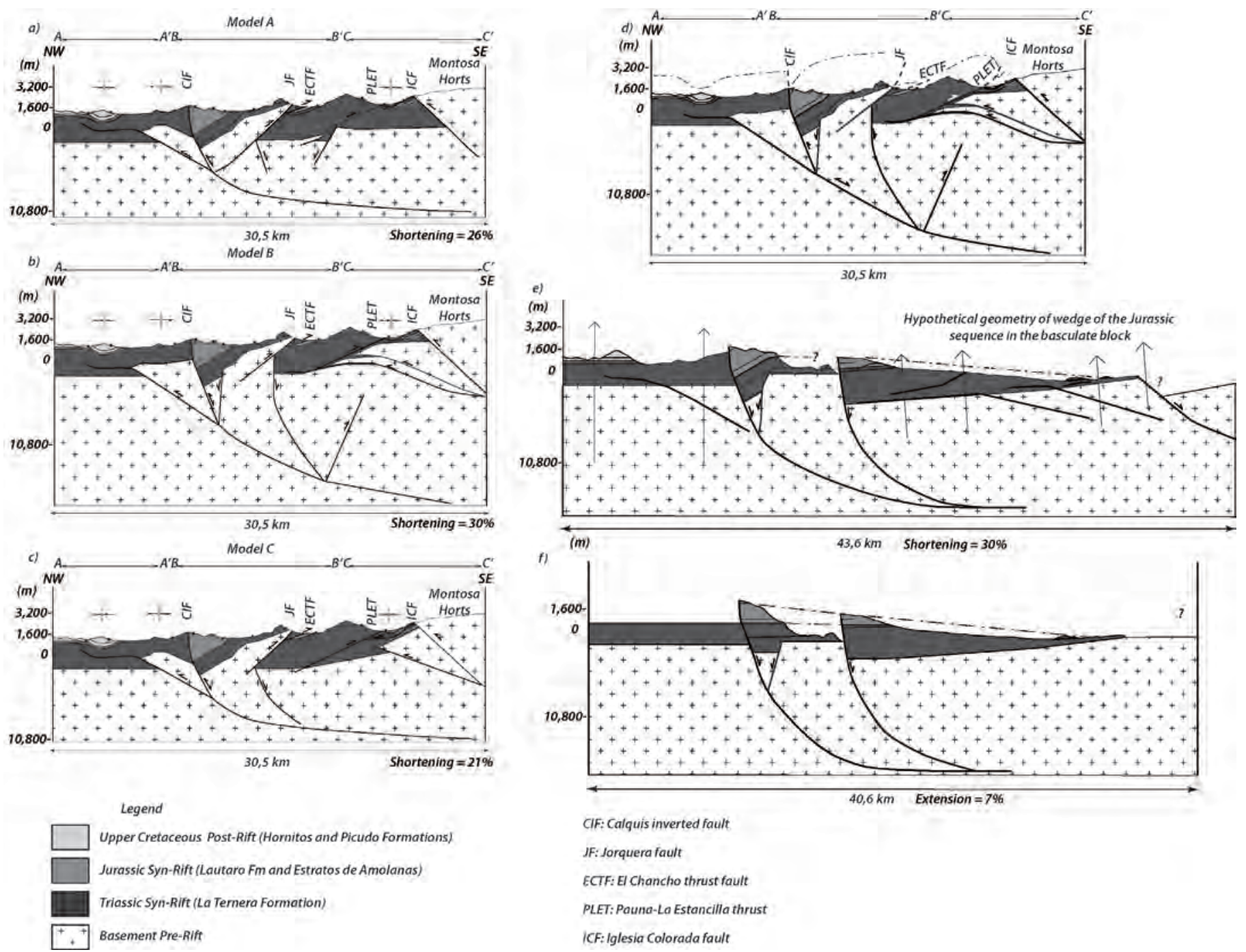

FIG. 6. a, b and c. Structural models proposed to explain the structure of the Lautaro Basin, based on the construction of balanced structural cross-sections. d, e and $\mathbf{f}$. Palinspastic restoration for Model B; d. Current state model for Lautaro Basin. e. Restoration to the Jurassic extension state. f. Restoration to the pre-Jurassic extension state. 


\section{Restored section and tectonic shortening}

To constrain shortening and extension estimates as well as the geometry and kinematics, the balanced cross-section was sequentially restored. This allowed us to obtain a pre-shortening stage or Jurassic extension state and a pre-extension Jurassic state (Figs. $6 \mathrm{~d}$, e and $\mathrm{f}$ ). However, an important assumption in section balancing is that there is no out of plane deformation. Our preferred model was obtained after a trial-and-error procedure during which the shapes of faulted blocks were progressively modified and simulated with the 2D-MOVE software. Even though all models fulfilled the requirement to reproduce the surface data, the model that better explains the observed structural styles, showing minimal gap and overlap problems and better preserving area and bed lengths in the restored state, is Model B (Figs. 6b and d).

The length of the cross-section presented in this study is $30.5 \mathrm{~km}$ (Fig. 6d). Once the contractional deformation was subtracted, the restored length of the cross-section is $43.6 \mathrm{~km}$, indicating that the total amount of minimum shortening for the entire section is $13.1 \mathrm{~km}$ or $30 \%$ and obtaining a Jurassic extension state (Fig. 6e). This section results from the integration of various structural segments that are parallel-distributed from north to south through the basin, so that the cumulative shortening has relative changes in each of them. For this reason, we have estimated a minimum shortening in the region, although the geometry of the structural styles in the architecture of the basin is maintained. This shortening would increase by about $2 \mathrm{~km}$ the crustal thickness in the cross-section area. The extensional deformation was subtracted to restore the Jurassic extension state, to this case the restored length of the cross-section was $40.6 \mathrm{~km}$ indicating that the total amount of Jurassic extension is $3 \mathrm{~km}$ or $7 \%$ (Fig. 6f).

According to the forward modeling applied to each of the models, and the vergence observed for the thick-skinned structures (which are basically those that control deformation in the basin), we were able to identify a preferential NE-SW direction of tectonic transport. It is possible that the oldest structures in the basin are located in the eastern portion and gradually rejuvenate toward the western side, although in an inversion tectonic process there is no clear tectonic control on the timing of the reactivation of previously formed structures.
Based on the analysis of the restorations made, we have proposed the following phases in the evolution of the Lautaro Basin:

\section{a. Development of a Mesozoic east-vergent half-} graben. At least two phases of extension are required to remove the extensional deformation affecting both the Paleozoic basement and Mesozoic successions. The faults used to restore this deformation have been assumed to be listric normal faults with a detachment depth of approximately $21,600 \mathrm{~m}$, as shown in the figure 6 . The restoration of models $\mathrm{A}$ and $\mathrm{C}$ are clearly inconsistent and were therefore discarded in this study. These inconsistencies are: a. to restore the Calquis Fault to its pre-Jurassic extension position, its basement in the hanging wall overthrusting the Triassic series in the footwall; $\mathbf{b}$. the thickness of the Triassic successions in the hanging wall of the Calquis Fault is smaller than in the footwall, which would be incompatible with extensional fault activity during the Triassic, as shown by field data.

Restoration of the pre-Jurassic extension, using the structural model proposed for the Lautaro Basin by model $\mathrm{B}$, defines a half-graben geometry dipping eastwards, which is mainly formed of synthetic faults although one antithetic fault to the Calquis Fault is also considered. Although there is not a clear unconformity between the Triassic and Jurassic syn-rift successions, the progressive unconformities observed within the Jurassic succession indicates tectonic activity during this period of time (Fig. 4b). Whitin this context, when the Jurassic extension is restored, a considerable variation in thickness is shown (Fig. 6) with a geometry and thickness different from that of the underlying Triassic synrift succession (Fig. 6). This stratigraphic variation enables us to deduce that the Lautaro Basin has undergone at least two extensional phases, which is consistent with the interpretations from Kay et al. (1989), Mpodozis and Kay (1990) and Suárez and Bell (1992).

b. Partial closure of a Mesozoic half-graben and development of thick-skinned thrust and thin-skinned reverse faults. We propose that in the eastern region of the Lautaro Basin, the Iglesia Colorada Fault propagates as an inherited fault, for which a constant dip angle of $45^{\circ} \mathrm{SE}$ is assumed (Fig. 6). The folding style recognized in the footwall of the Iglesia Colorada Fault appears to be related to fault propagation folding, because the Jurassic and Cretaceous beds form an inclined limb of the 
typical syncline developed at the footwall of these structure (Figs. 3a, 5d and 6). By using trishear modeling we have assumed a $\mathrm{p} / \mathrm{s}$ relation $=0$, with displacements of $10-15 \mathrm{~m}$. The formation of thick-skinned blind structures in the eastern basin emerges as an efficient mechanism to accommodate the deformation beneath the triangle zone occurring between the Pauna-La Estancilla Thrust and the Iglesia Colorada Fault (Fig. 6). The intense thinskinned deformation of the Mesozoic successions in this area is the fundamental condition assumed for this interpretation. The main difference in the three models is the thickness of the Triassic succession, the number of tectonic sheets positioned in front of the Iglesia Colorada Fault, and the main deformation mechanism of the overburden. The palinpastic cross-sections of Model B show that as the Mesozoic successions gradually thin towards the $\mathrm{E}$ of the basin, there are mechanically detached to accommodate the deformation of the thick-skinned Iglesia Colorada Fault (Figs. 6d, e and f).

For all models in the western region, the hanging wall of the Calquis Fault represents a rollover anticline formed during Jurassic extension, which then buttressed over a rigid ramp during partial closure of the basin (Fig. 6). This led to the formation of back-thrust and short-cut structures. The development of these styles has been well documented by Bonini et al. (2000), Mitra (2002), Turienzo and Dimieri (2005) and Carrera et al. (2006).

\section{Discussion}

In the Central Andes of northern Chile, within the western edge of the Frontal Cordillera domains, the structural and stratigraphic relations observed in the main Mesozoic depocenters indicate different structural styles. Traditional structural studies carried out in these regions have established the existence of Mesozoic depocenters associated with the pre-Andean tectonic cycle, forming a NNW-SSE structural pattern, which has been correlated with similar cases on the Argentine side (e.g., Tarapacá Basin, Uliana and Biddle, 1988; Ramos and Kay, 1991).

The Mesozoic deposits in these depocenters were controlled by major faults with the same orientation, some of which were reactivated during subsequent episodes of deformation (Charrier, 1979, Charrier et al., 2007). Similarly, it has formed major oppositevergent thick-skinned thrust fault systems (Reutter,
1974; Jensen, 1976, Nassi et al., 1985; Ribba, 1986; Soffia, 1989; Moscoso and Mpodozis, 1988), as well as inverted structures, which can be observed in the Domeyko Cordillera (Amilibia et al., 2008). A good example of the Mesozoic depocenters in the western part of the northern Chilean Andes is the Lautaro Basin. The tectono-stratigraphic relationships in this depocenter allowed us to establish an asymmetric configuration with a preferential NNE-SSW orientation, which is controlled by major faults such as the Calquis Inverted Fault. This configuration differs from the NNW-SSE pattern in the Mesozoic depocenter proposed for northern Chile by Charrier (1979) and Moscoso et al. (1982), but coincides with the Jurassic basin structure proposed by Ramos (2009) for the western part of central and southern South America.

Due to the asymmetric geometry of the basin, the length of the master faults and the poor development of en echelon fault patterns, we assume a nearly orthogonal crustal extension in the formation of the Lautaro Basin. In this basin the Calquis Fault has a certain obliquity to reactivated normal faults affecting the Triassic syn-rift successions (e.g., the Pauna-La Estancilla Thrust). Similar cases have been reported from related models carried out by Michon and Sokutis (2005), which consider that the oblique array of faults within an extensional basin is closely relateded to: a. the distribution of lithospheric features and preexisting crustal structures; b. rheological changes of the basement, and $\mathbf{c}$. the reactivation and inversion of accommodation zones. The latter is capable of reproducing a break in the strike of the Calquis Fault. Some models (Etheridge, 1986; Keep and McClay, 1997; Konstantinovskaya et al., 2007), have demonstrated that in inverted accommodation zones, it is very common that similar geometries develop resulting from the formation of lateral ramps connecting the basin edges.

The restoration of balanced cross-sections has enabled us to interpret at least one episode of positive tectonic inversion in the basin, from the contraction of structures formed by extension of the upper crust of the western margin of South America during the Mesozoic (Charrier, 1979; Suárez and Bell, 1992; Mpodozis and Kay 1990; Charrier et al., 2007). This establishes the influence of pre-existing normal faults in the subsequent shortening of the western margin of northern Chile. We propose that the geometry of the basin and the structures that comprise it, represent a partially inverted half-graben. The inherited 
Triassic and Jurassic normal faults have played an important role in the development of younger structural styles, which reflect the pattern of the present Andean deformation. The proposed models for the deep structure of the basin indicate that the greater part of the orientation and distribution of thick- and thin-skinned structures were controlled by pre-existing extensional faults, as shown by palinspastic restorations (Fig. 6).

The tectonic shortening accommodated by these structures during the partial inversion of the basin is $30 \%$ equivalent to $13.1 \mathrm{~km}$, which is consistent with recent estimates in the northernmost regions such as the Cordillera de Domeyko (Amilibia et al., 2008), and higher than those calculated for certain regions of the Frontal Cordillera in Argentina and the Sierras Pampeanas (Cristallini et al., 1997) in the Puna Plateau. Previous studies conducted throughout the region (Jensen, 1976; Soffia, 1989) have estimated shortening values of $25 \%$, while to the south of the Tránsito River, Reutter (1974) estimated 40\% in thick-skinned structures. However structural sections constructed in the Domeyko Cordillera, have values of $20 \%$ in thick-skinned and $40 \%$ in thin-skinned styles, respectively (Amilibia et al., 2008). A value of $7 \%$ equivalent to $3 \mathrm{~km}$ of lithospheric stretching is estimated in our palinspastic Jurassic extension, which allows us to interpret that this tectonic event allowed the creation of a deep depocenter in the region. The Triassic syn-rift successions could have been deposited in a wider extensional basin, due to the higher density of faulting and the interaction between crustal extension and thermal relaxation during the Late Triassic rifting. The partial closure of the Lautaro Basin is related to the crustal thickening process from a fragile horizons within of the continental crust. Although we do not have good enough control on the age of compression, according to regional data from neighboring areas, this is estimated as Late Cretaceous-Paleogene. However, more detailed studies are needed to better refine the timing of the compressional events.

\section{Conclusions}

Based on new structural and stratigraphic data collected for the Lautaro Basin, the detailed observation of characteristics of the stratigraphic successions involved in the deformation, as well as the different geometries of the structural styles and the construction of balanced and palinspastic cross-sections, we conclude that:

The Lautaro Basin is defined as a partially inverted half-graben trending NNE-SSW, containing a stratigraphic thickness of at least 4,000 m of Triassic and Jurassic syn-rift successions (La Ternera and Lautaro Formations, respectively). Those deposits overlie Upper Paleozoic granites, showing clear evidence of contractional deformation associated with tectonic shortening, possibly initiated in the Late Cretaceous, with a main E-W vergence.

The principal structural styles are represented by partially inverted normal faults, (e.g., the Calquis Fault), short-cut, back-thrust and accommodation zones, defining a deformation pattern dominated by inversion tectonic processes. From $\mathrm{E}$ to $\mathrm{W}$ there is an important combination of thick- and thin-skinned deformation along thrust faults dipping at moderate to high angles $\left(45^{\circ}-60^{\circ} \mathrm{W}\right)$ and back-thrust structures originating at the base of the major fault ramps, accommodating the tectonic shortening in the upper portion of the basin.

The major structures that control the asymmetric geometry of the NNE-SSW trending Lautaro Basin are, from $\mathrm{E}$ to $\mathrm{W}$, the Calquis Fault, and the Iglesia Colorada Fault, verging E. The remaining structures are considered to be thin-skinned secondary faults resulting from the initial tectonic inversion of the thick-skinned fault set, generating greater deformation in the Mesozoic cover.

The drastic changes in thickness observed in the Mesozoic stratigraphic successions through structures such as the Calquis Fault, Pauna-La Estancilla Thrust, and the El Chancho Thrust have allowed us to interpret a series of extensional thick-skinned structures, that define La Ternera Formation and Lautaro Formation as syn-rift successions controlled by these structures that are possibly inherited from the rifting of Middle Triassic and Late Jurassic age affecting the western edge of the Central Andes.

Successive extensional deformation during the Mesozoic and possible rheological changes of the basement as well as reactivation and inversion of the accommodation zones, were able to reproduce the break in the strike of the Calquis Fault, which has been documented with good approximations in similar models (Etheridge, 1986; Keep and McClay, 1997; Michon and Sokutis, 2005; Konstantinovskaya et al., 2007). 
According to the proposed structural model for the structure of the Lautaro Basin (Model B), the tectonic inversion of pre-existing extensional faults, in a context of synthetic and antithetic partially inverted faults, and thin-skinned back-thrust are the manner in which the Andean deformation, at least in the studied region, was absorbed the major shortening in the area.

The tectonic shortening estimated for the Lautaro Basin varies between 21\%-30\% equivalent to $13.1 \mathrm{~km}$, which is greater than estimations for the northernmost regions (e.g., Cordillera de Domeyko), but less than the calculated shortening in the southernmost regions (e.g., El Tránsito River) along the western margin of northern Chile. The restoration of the Jurassic pre-extension time leads to estimates ranging from 2\%-7\% equivalent to $\sim 3 \mathrm{~km}$.

Although we have no data to establish a specific age of deformation, much of the shortening is estimated as being Late Cretaceous-Paleogene, according to regional data from neighboring areas.

\section{Acknowledgements}

Financial support for this project was provided by Fondo Nacional de Desarrollo Científico y Tecnológico (FONDECYT), Chile (grants 1050750 and 1070964) and by the Institut de Recherche pour le Développent (IRD). Midland Valley kindly provided us the 2D MOVE software to perform part of the study. Comments from R. Charrier and J. Le Roux helped reorganize and clarify the content of the paper. We would also like to thank S. Villagrán and M. Vaccaris for assistance in the field. We thank T. Jordan and L. Giambiagi for detailed thoughtful reviews that improved the manuscript.

\section{References}

Amilibia, A.; Sàbat, F.; McClay, K.R.; Muñoz, J.A.; Roca, E.; Chong, G. 2008. The role of inherited tectonosedimentary architecture in the development of the central Andean mountain belt: Insights from the Cordillera de Domeyko. Journal of Structural Geology 30 (12): 1520-1539.

Arévalo, C.; Rivera, O.; Iriarte, S.; Mpodozis, C. 1994. Cuencas extensionales y campos de calderas del Cretácico Superior-Terciario Inferior en la Precordillera

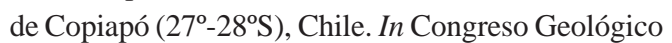
Chileno, No. 7, Actas 2: 1288-1292. Concepción.

Arévalo, C. 2005. Carta Los Loros, Región de Atacama. Servicio Nacional de Geología y Minería, Carta
Geológica de Chile, Serie Geología Básica 92: 54 p. 1 mapa escala 1:100.000.

Arriagada, C.; Roperch, P.; Mpodozis, C. 2000. Clockwise block rotations along the eastern border of the Cordillera Domeyko, northern Chile (22 $\left.45^{\circ}-23^{\circ} 30^{\prime} \mathrm{S}\right)$. Tectonophysics 326: 153-171.

Arriagada, C.; Roperch, P.; Mpodozis, C.; Dupont- Nivet, G.; Cobbold, P.R.; Chauvin, A.; Cortés, J. 2003. Paleogene clockwise tectonic rotations in the fore-arc of central Andes, Antofagasta region, northern Chile. Journal of Geophysical Research 108 (B1): 101-122.

Arriagada, C.; Roperch, P.; Mpodozis, C.; Fernández, R. 2006a. Paleomagnetism and tectonics of the southern Atacama Desert region (25-28 $\mathrm{S})$ Northern Chile. Tectonics 25 (TC4001): 1-26.

Arriagada, C.; Cobbold, P.; Roperch, P. 2006b. Salar de Atacama basin: A record of compressional tectonics in the central Andes since the mid-Cretaceous. Tectonics 25 (TC1008): 1-19.

Arriagada, C.; Roperch, P.; Mpodozis, C.; Cobbold, P.R. 2008. Paleogene building of the Bolivian Orocline: Tectonic restoration of the central Andes in 2-D map view. Tectonics 27 (TC6014): 1-14.

Audemard, F.E 1991. Tectonics of Western of Venezuela. Ph.D. Thesis (Unpublished), Rice University: 245 p.

Bonini, M.; Sokoutis, D.; Mulugeta, G.; Katrivanos, E. 2000. Modelling hanging wall accommodation above rigid thrust ramps. Journal of Structural Geology 22: 1165-1179.

Brüggen, H. 1950. Fundamentos de la Geología de Chile. Instituto Geográfico Militar: 510 p. Santiago de Chile.

Butler, R. 1989. The influence of pre-existing basin structure on thrust system evolution in the Western Alps. In Inversion Tectonics (Cooper, M.; Williams, G.; editors). Geological Society of London, Special Publication 44: 105-122.

Butler, R.; Tavarnelli, E.; Grasso, M. 2006. Structural inheritance in mountain belts: An Alpine-Apennine perspective. Journal of Structural Geology 28: 18931908.

Cahill, T.; Isacks, B.L. 1992. Seismicity and shape of the subducted Nazca Plate. Journal of Geophysical Research 97 (17): 503-529.

Carrera, N.; Muñoz, J.A.; Sábat, F.; Mon, R.; Roca, E. 2006. The role of inversion tectonics in the structure of the Cordillera Oriental (NW Argentinean Andes). Journal of Structural Geology 28: 1921-1932.

Charrier, R. 1979. El Triásico en Chile y regiones adyacentes de Argentina: Una reconstrucción paleogeográfica y paleoclimática. Comunicaciones 26: 1-47. 
Charrier, R.; Pinto, L.; Rodríguez, M.P. 2007. Tectonostratigraphic evolution of the Andean Orogen in Chile. In The Geology of Chile (Moreno, T.; Gibbons, W.; editors). The Geological Society: 21-114. London

Cooper, M.; Williams, G. 1989. Inversion structures, recognition and characteristics. In Cooper, M.; Williams, G.; editors). Inversion Tectonics. Geological Society of London, Special Publication 44: 341-347.

Cristallini, E.; Comínguez, A.H.; Ramos, V.A. 1997. Deep structure of the Metán-Guachipas region: tectonic inversion in Northwestern Argentina. Journal of South American Earth Sciences 110: 403-421.

Cristallini, E.; Bottesi, G.; Gavarrino, A.; Rodríguez, L.; Tomezzoli, R.; Comeron, R. 2006. Synrift geometry of the Neuquén Basin in northeastern Neuquén Province, Argentina. Geological Society of America, Special Paper 407: 148-161.

Dellapé, D.; Hegedus, A. 1995. Structural Inversion and Oil Ocurrence in the Cuyo Basin of Argentina. American Association of Petroleum Geologists, Memoir 62: 359-367.

DiCarlo, D.; Cristallini, E. 2007. Estructura de la margen norte del Río Grande, Bardas Blancas, Provincia de Mendoza. Revista de la Asociación Geológica Argentina 62: 187-199.

Escalona, E.; Mann, P. 2006. An overview of the petroleum system of the Maracaibo Basin. American Association of Petroleum Geologists 90: 657-678.

Etheridge, M.A. 1986. On the reactivation of extensional fault systems. Philosophical Transactions of the Royal Society of London, Series A. Mathematical and Physical Sciences 317: 179-194.

Farrar, E.; Clark, A.H.; Haynes, S.J.; Quirt, G.; Conn, H.; Zentilli, M. 1970. K-Ar evidences for the post-Paleozoic migration of magmatic foci in the Andes of northern Chile. Earth and Planetary Science Letters 10: 60-66.

Forsythe, R.; Chisholm L. 1994. Paleomagnetic and structural constraints on rotations in the north Chilean coast ranges. Journal of South American Earth Science 7: 279-294.

Godoy, E.; Davidson, J. D. 1976. Pilares en compresión de edad Mioceno superior en los Andes del Norte de Chile ( $22^{\circ}-30^{\circ}$ Latitud Sur). In Congreso Geológico Chileno, No. 1, Actas B: 87-103.

Giambiagi, L.B.; Ramos, V.A.; Godoy, E.; Álvarez, P.P.; Orts, S. 2003. Cenozoic deformation and tectonic style of the Andes, between $33^{\circ}$ and $34^{\circ}$ South Latitude. Tectonics 22: 1-18.

Hartley, A.J.; Jolley, E.J.; Turner, P. 1992. Paleomagnetic evidence for rotation in the Precordillera of northern
Chile: Structural constraints and implications for the evolution of the Andean forearc. Andean Geodynamics. Tectonophysics 205: 49-64.

Iriarte, S.; Arévalo, A.; Mpodozis, C. 1999. Hoja La Guardia, Región de Atacama. Servicio Nacional de Geología y Minería, Mapas Geológicos 13, escala 1:100.000.

Isacks, B.L. 1988. Uplift of the central Andean plateau and bending of the Bolivian orocline. Journal of Geophysical Research 93: 3211-3231.

Jensen, O. 1976. Geología de las nacientes del río Copiapó, entre los $27^{\circ} 53^{\prime}$ y $28^{\circ} 20^{\prime}$ de latitud Sur, provincia de Atacama, Chile. Memoria de Titulo (Inédito), Universidad de Chile, Departamento de Geología: 249 p.

Jensen, O.; Vicente, J.C. 1976. Estudio geológico del área de "Las Juntas" del río Copiapó (Provincia de Atacama-Chile). Revista de la Asociación Geológica Argentina 21 (3): 145-173.

Jensen, O. 1985. Potencial petrolífero del Mesozoico marino en la Cuenca de Atacama; consideraciones en relación a su historia de subsidencia, evolución geotérmica y posibilidades generativas. In Congreso Geologico Chileno, No. 4, Actas 2: 3.651-3.673. Antofagasta.

Jordan, T.E.; Mpodozis, C.; Muñoz, N.; Blanco, P.; Pananont, M.; Gardeweg. 2007. Cenozoic subsurface stratigraphy and structure of the Salar de Atacama basin, northern Chile. Journal of South American Earth Sciences 23: 122-146.

Kay, S.M.; Ramos, V.A.; Mpodozis, C.; Sruoga, P. 1989. Late Paleozoic to Jurassic silicic magmatism at the Gondwana margin: Analogy to the middle Proterozoic in North America? Geology 17: 324-328.

Keep, M.; McClay, K. 1997. Analogue modelling of multiphase rift systems. Tectonophysics 273: 239-270.

Keller, J.; McClay, K. 1995. 3D sandbox models of positive inversion. In Basin Inversion (Buchanan, J.; Buchanan, P.; editors). Geological Society of London, Special Publication 88: 137-146.

Konstantinovskaya, E.; Harris, L.; Poulin, J.; Ivanov, G. 2007. Transfer zones and fault reactivation in inverted rift basins: Insights from physical modelling. Tectonophysics 441: 1-26.

Lamb, S.; Hoke, L. 1997. Origin of the high Plateau in the central Andes, Bolivia, South America. Tectonics 16: 623-649.

McClay, K. 1995. The geometries and kinematics of inverted fault systems: a review of analogue model studies. In Basin Inversion (Buchanan, J.; Buchanan, P.; editors). Geological Society of London, Special Publication 88: 97-118. 
McQuarrie, N.; DeCelles, P. 2001. Geometry and structural evolution of the central Andean backthrust belt, Bolivia. Tectonics 20: 669-692.

Maksaev, V.; Zentilli, M. 1999. Fission track thermochronology of the Domeyko Cordillera, northern Chile: Implications for Andean tectonics and porphyry copper metallogenesis. Exploration and Mining. Geology 8: 65-89.

Maksaev, V.; Munizaga, F.; Valencia. V.; Barra, F. 2009. LA-ICP-MS zircon U-Pb geochronology to constrain the age of post-Neocomian continental deposits of the Cerrillos Formation, Atacama Region, northern Chile: tectonic and metallogenic implications. Andean Geology 36 (2): 264-287.

Martínez, F.; Roux, J.; Castillo, J.F.; Bastardo, M.; Carrasquel, M. 2010. Relación de la deformación extensional y contractiva en la región centro-sur de la Cuenca de Maracaibo: implicancias para el desarrollo de potenciales trampas petrolíferas. Interciencia 35: 883-890.

Michon, L.; Sokoutis, D. 2005. Interaction between structural inheritance and extension direction during graben and depocentre formation: An experimental approach. Tectonophysics 409: 125-146.

Mitra, S.; Mount, V. 1998. Foreland basement-involved structures. American Association of Petroleum Geologists Bulletin 82 (1): 70-109.

Mitra, S. 2002. Fold-accommodation faults. American Association of Petroleum Geologists Bulletin 86: 671-693.

Mora, A.; Parra, M.; Strecker, M.; Kammer, A.; Dimaté, C.; Rodríguez, F. 2006. Cenozoic contractional reactivation of Mesozoic extensional structures in the Eastern Cordillera of Colombia. Tectonics 25. doi: 10.1029/2005TC001854.

Moscoso, R.; Padilla, H.; Rivano, S. 1982. Hoja Los Andes, Región de Valparaíso. Servicio Nacional de Geología y Minería, Carta Geológica de Chile 52: 67 p., 1 mapa escala 1:250.000.

Moscoso, R.; Mpodozis, C. 1988. Estilos estructurales en el Norte chico de Chile $\left(28^{\circ}-31^{\circ} S\right)$, regiones de Atacama y Coquimbo. Revista Geológica de Chile 15: $155-158$.

Moscoso, R.; Mpodozis, C.; Nasi, C.; Ribba, L.; Arévalo, C. (Compilador) 2010. Geología de la Hoja del Tránsito, Región de Atacama. Servicio Nacional de Geología y Minería de Chile, Carta Geológica de Chile, Serie Preliminar 7: 17 p., 1 mapa escala 1:250.000.

Mpodozis, C.; Ramos, V.A. 1990. The Andes of Chile and Argentina. In Geology of the Andes and its relation to hydrocarbon and energy resources. Circum-Pacific
Council for Energy and Hydrothermal Resources (Ericksen, G.E.; Cañas, M.T.; Reinemund, J. A.; editors). American Association of Petroleum Geologists, Earth Science Series: 59-90. Houston, Texas.

Mpodozis, C.; Kay, S. M. 1990. Provincias magmáticas ácidas y evolución tectónica de Gondwana: Andes chilenos $\left(28^{\circ}-31^{\circ}\right.$ S). Revista Geológica de Chile 17: (2) 153-180.

Mpodozis, C.; Kay, S. M. 1992. Late Paleozoic to Triassic evolution of the Gongwana margin: Evidence from Chilean Frontal Cordilleran batholiths ( $28^{\circ} \mathrm{S}$ to $31^{\circ} \mathrm{S}$ ). Geological Society of America Bulletin 104: 999-1014.

Mpodozis, C.; Cornejo, P. 1997. El rift Triásico- Sinemuriano de Sierra Exploradora, Cordillera de Domeyko $\left.25^{\circ}-26^{\circ} \mathrm{S}\right)$ : Asociaciones de facies y reconstrucción tectónica. In Congreso Geológico Chileno, No. 8, Actas: 1550-554. Antofagasta.

Mpodozis, C.; Arriagada, C.; Basso, P.; Roperch, P.; Cobbold, P.; Reich, M. 2005. Mesozoic to Paleogene stratigraphy of the Atacama (Purilactis) Basin, Antofagasta region, northen Chile: insight into the earlier stages of central Andean tectonic evolution. Tectonophysics 399: 125-154.

Mpodozis, C.; Ramos, V. 2008. Tectónica Jurásica en Argentina y Chile: Extensión, subducción oblicua, rifting, deriva y colisiones? Revista de la Asociación Geológica Argentina 63 (4): 479-495.

Mugnier, J.; Huyghe, P. 1995. A comparison of inverted basins of the Sourthern North Sea and inverted structures of the external Alps. In Basin Inversion (Fleet, A.J.; editors). The Geologycal Society Special Edition 88: 339-353. London.

Muñoz, N.; Charrier, R.; Jordan, T.E. 2002. Interactions between basement and cover during the evolution of the Salar de Atacama basin, northern Chile. Revista Geológica de Chile 29 (1): 3-29.

Nasi, C.; Mpodozis, C.; Cornejo, P.; Moscoso, R.; Maksaev, V. 1985. El batolito Elqui-Limarí (Paleozoico Superior-Triásico). Características petrográficas, geoquímicas y significado tectónico. Revista Geológica de Chile 25-26: 77-111.

Neely, T.; Erslev, E. 2009. The interplay of fold mechanism and basement weaknesses at the transition between Laramide basement-involved arches, north-central Wyoming, U.S.A. Journal of Structural Geology. doi:10.1016/j.jsg.2009.03.008.

Ramos, A. 2009. Anatomy and global contexto $f$ the Andes: Main geologic features and the Andean orogenic cycle. The Geological Society of America Memoir 204:31-65. 
Ramos, V.A.; Kay, S. M. 1991. Triassic rift basalts of the Cuyo Basin, central Argentina, In Andean Magmatism and its Tectonic Setting (Harmon, R.S.; Rapela, C.W.; editors). Geological Society of America, Special Publication 265: 79-91.

Randall, D.E.; Taylor, G.K.; 1996. Major crustal rotations in the Andean margin: Paleomagnetic results from the coastal Cordillera of Northern Chile. Journal of Geophysical Research 101 (15): 783-798.

Reutter, K. J. 1974. Entwicklung und Bauplan der chilenischen Hochkordillere im Bereich $29^{\circ}$ südlicher Breite. Neues Jahrbuch für Geologie und Paläontologie 146 (2): 153-178.

Ribba, L. 1986. Geología del Cuadrángulo El Tránsito, Región de Atacama, Chile. Memoria de Título (Inédito), Universidad de Chile, Departamento de Geología: 214 p.

Riley, P.D.; Beck, M.E.J.; Burmester, R.F.; Mpodozis, C.; García, A. 1993. Paleomagnetic evidence of vertical axis block rotations from the Mesozoic of northern Chile. Journal of Geophysical Research 98: 8321-8333.

Schmitz, M. 1994. A balanced model of the southern central Andes. Tectonics 13: 484-492.

Segerstrom, K.; Parker, R.L. 1959. Geología del cuadrángulo Copiapó. Instituto de Investigaciones Geológicas, Santiago, Carta Geológica de Chile 3: 115 p.

Segerstrom, K. 1968. Geología de las Hojas Copiapó y Ojos del Salado, Provincia de Atacama. Instituto de Investigaciones Geológicas, Santiago, Carta Geológica de Chile 24: 58 p., escala 1: 250.000.

Sepúlveda, P.; Naranjo, J.A. 1982. Hoja Carrera Pinto. Servicio Nacional de Geología y Minería, Carta Geológica de Chile 53: 62 p., 1 mapa escala 1:100.000.

Sheffels, B.M. 1990. Lower bound on the amount of crustal shortening in the central Bolivian Andes. Geology 23: 812-815.

Soffia, J.M. 1989. Estratigrafía y geología estructural del área del río Jorquera, Región de Copiapó. Memoria de Título (Inédito), Universidad de Chile, Departamento de Geología: 159 p.

Solms-Laubach, J.; Steinmann, G. 1889. Das Auftreten und die Flora der rhätischen Kohlenschichten von La Ternera (Chile). Neues Jahrbuch für Mineralogie. Geologie und Palaeontologie 12: 581-609.

Somoza, R.; Tomlinson, A. 2002. Paleomagnetism in the Precordillera of northern Chile (22 30 'S): Implications for the history of tectonic rotations in the central Andes. Earth Planet Science Letters 194: 369-381.

Stone, D. 2003. New interpretations of the Piney Creek thrust and associates Granite Ridge tear fault, nor- theastern Bighorn Mountains, Wyoming. Rocky Mountain. Geology 38 (2): 205-235.

Suárez, M.; Bell, M. 1992. Triassic rift-related sedimentary basins in northern Chile $\left(24^{\circ}-29^{\circ} \mathrm{S}\right)$. Journal of South American Earth Sciences 6: 109-121.

Suppe, J. 1983. Geometry and kinematics of fault bend folding. American Journal of Science 283: 684-721.

Suppe, J.; Medwedeff, D.A. 1984. Fault-propagation folding. Geological Society of America 16: 670.

Suppe, J. 1985. Principles of structural geology. Englewood Cliffs. Prentice-Hall: 537 p. New Jersey.

Suppe, J.; Chou, G.T.; Hook, S.C. 1992. Rates of folding and faulting determined from growth strata. In Thrust Tectonics (McClay, K.R.; editor). Chapman \& Hall: 105-121. Londres.

Taylor, G.; Grocott, J.; Pope, A.; Randall, D. 1998. Mesozoic fault systems, deformation and fault block rotation in the Andean forearc: A crustal scale strike-slip duplex in the Coastal Cordillera of Northern Chile. Tectonophysics 299: 93-109.

Taylor, G.K.; Grocott, J.; Daswood, B.; Gipson, M.; Arévalo, C. 2007. Implications for crustal rotation and tectonic evolution in the Central Andes fore-arc: New paleomagnetic results from the Copiapó region of northern Chile, $26^{\circ}$ to $28^{\circ} \mathrm{S}$. Journal of Geophysical Research. doi: 10.1029/2005JB003950.

Turienzo, M.; Dimieri, L.V. 2005. Interpretación de la estructura del frente montañoso en la zona del río Diamante, Mendoza. Revista de la Asociación Geológica Argentina 60 (2): 336-352.

Uliana, M.A.; Biddle, K.T. 1988. Mesozoic-Cenozoic paleogeographic and geodynamic evolution of southern South America. Revista Brasileira de Geociencias 18: 172-190.

Uliana, M.; Arteaga, M.; Legarreta, L.; Cerdán, J.; Peroni, G. 1995. Inversion structures and hydrocarbon occurrence in Argentina. In Basin Inversion (Fleet, A.J.; editors). The Geologycal Society Special Edition 88: 211-233.

Von Hillebrant, A.; Gröscke, M.; Prinz, P; Wilke, H-G. 1986. Marines Mesozoikum in Nordchile zwischen $21^{\circ}$ und $26^{\circ}$ S. Berliner Geowissenschaftliche Abhandlungen, (A). Geologie und Palaeontologie 66 (1): 169-190. 66: 169-190.

Yagupsky, D.; Cristallini, E.; Fantín, J.; Valcarte, G.; Bottesi, G.; Varadé, R. 2008. Oblique half-graben inversion of the Mesozoic Neuquén Rift in the Malargüe Fold and Thrust Belt, Mendoza, Argentina: New insights from analogue models. Journal of Structural Geology 30: 839-853. 
Yamada, Y.; McClay, K. 2004. 3D Analog modeling of thrust structures. American Association of Petroleum Geologists, Memories 82: 276-301.

Zapata, R.; Allmendinger, R. 1996. Growth stratal records of instantaneous and progressive limb rotation in the
Precordillera thrust belt and Bermejo basin, Argentina. Tectonics 15: 1065-1083.

Zentilli, M. 1974. Geological evolution and metallogenic relationships in the Andes of N. Chile. Ph.D. Thesis (Unpublished), Queen’s University: 446 p. Canada. 